\title{
The Profile of Dyslexic Children
}

\author{
Mutiara Mardina \\ Social Welfare Program Study FISIP \\ University of Padjadjaran \\ Sumedang City \\ mutiaramardina3@gmail.com \\ Nurliana Cipta Apsari \\ Family and Child Welfare Research Center \\ University of Padjadjaran \\ Sumedang City nurliana.cipta.apsari@unpad.ac.id
}

\author{
Santoso Tri Raharjo \\ Community Development and CSR Research Center \\ University of Padjadjaran \\ Sumedang City santoso.tri.raharjo@unpad.ac.id
}

Sahadi Humaedi

Community Development and CSR Research Center

University of Padjadjaran

Sumedang City sahadihumaedi@gmail.com

\begin{abstract}
Dyslexic research that examines the background of individuals with dyslexia is still small.. Most of them research on biographies in general individuals with dyslexia. Whereas by knowing the individual dyslexia then can exactly in providing solutions as needed. Therefore, this study aims to find out how the profile of individuals with dyslexia, especially in the city of Bandung. This study was conducted on one of dyslexic associations in Bandung using type of research suvei with 30 respondents. This research is a descriptive research with qualitative approach so that it can give picture of dyslexic background. In taking data using brief interviews, questionnaires and secondary data collection. Profile of respondent will explain about by age, gender, Residence (Domicile), education, parent job, parent education and religion. From the results that have been obtained From the results of 30 respondents obtained dyslexia profile results in the city of Bandung are: the majority of people with dyslexia aged 7 years with most male sex. People with dyslexia in the city of Bandung have the majority of employment as entrepreneurs with the last high school education and bearing the religion of Islam as many as 27 people.
\end{abstract}

Keywords: dyslexia, children, learning disabilitas

\section{INTRODUCTION}

The general public sees dyslexia as a term that is rarely heard and not many people know it. So, dyslexia less likely becomes a topic that most people know and understand. On the other hand, individuals who suffer dyslexia need a special concern from other normal individuals. Dyslexia is an intellectual disability or a literacy disorder so that the ability of literacy of an individual is different or considered left behind from other normal individuals. Besides affecting the literacy ability, dyslexia also affects a speaking ability for some sufferers.
Dyslexia is not limited to someone's inability to arrange or read a sentence only in a reversed order but also in various orders, including top to bottom orders. The Writers find this dysfunction is caused by condition from the unstable brain biochemistry and also some genetic causes from parents. According to WHO, 1 of 10 children in the world suffers from dyslexia. Then, Riyani T. Bonda (Chief of Indonesian Dyslexia Association) states that in the world, $10 \%-15 \%$ students suffer from dyslexia[1]. With the number of students in Indonesia, which is approximately fifty million, around five million students suffer from dyslexia. The number is quite large so there must be a special treatment for dyslexic individuals. It is needed a proper treatment so that the development of potency of dyslexic children does not get obstruent. It is because, as what Purboyo Solek (a pediatrician) says, dyslexic children have a huge potential. Children with dyslexia have a normal or above-average intelligence. It differentiates children with a specific learning difficulty like dyslexia with a general learning difficulty. Furthermore, Solek states that "Different to children with a learning difficulty who have a below-average intelligence level, like atypical absence seizures, down syndrome, and a number of autistic cases, dyslexia often gets mixed up with other learning difficulties". A couple of popular and influential figures, such as Albert Einstein (scientist), Tom Cruise (actor), Orlando Bloom (actor), Whoopi Goldberg (actress), and Lee Kuan Yew (former Prime Minister of Singapore), have been recorded as a dyslexic sufferer.

According to Indonesian Paediatrician Association (IDAI), dyslexia is a disorder in the development of literacy that generally occurs in children at the age of seven or eight years old. The symptom is that a child has a difficulty to read fluently and understand even though he/she is normal or above-average. It is included into a difficulty in the field of phonology, language ability/verbal understanding. Dyslexia is the most common learning difficulty and the 
most popular reading disorder. There are other difficulties in reading but they do not relate to dyslexia. This paper attempts to describe briefly and generally regarding the background of those who are identified suffering from dyslexia, particularly in Bandung City. A simple study result poured into this paper is hopefully able to enrich the resource about dyslexia. So in the end, the paper can upgrade the understanding of general public towards this issue. The upgrading of understanding of general public is hopefully followed by a correct response for children with dyslexia.

\section{METHOD}

This study is conducted descriptively with the qualitative approach. The aim of this study is to give a description regarding dyslexia in a children group. Generally, the description can be in the form of literature or the data from the field. A brief interview is done to 30 parents whose children with dyslexia and the members of dyslexia community in Bandung. Besides, the writers also collect the secondary data to complete a description of children with dyslexia.

Discussion In this part, it can be seen the general data towards children with dyslexia (ADD) from informants. The data are classified based on their age, sex, domicile, education, parents' job,

Table 1.

\begin{tabular}{|l|c|c|}
\hline Age of Respondents \\
\hline Age & Total & $\%$ \\
\hline 4 & 2 & $7 \%$ \\
\hline 5 & 3 & $10 \%$ \\
\hline 6 & 4 & $13 \%$ \\
\hline 7 & 9 & $30 \%$ \\
\hline 8 & 8 & $27 \%$ \\
\hline 10 & 4 & $13 \%$ \\
\hline Total & 30 & $100 \%$ \\
\hline
\end{tabular}

Table 1 shows that some children who suffer from dyslexia have just been found out approaching the school ages, namely preschool and primary school. It starts to be found out when the children behavior development is different to other children at the same age. Sixty percent children approaching primary school experience a difference in receiving the symbols of letter and number when they are learning Indonesian language and maths. The data from Table 1 also implies that most of the children with dyslexia have just been detected when they are entering the school period, which is at seven years old. It is in a line with the research done by Timothy $C$. Papadopoulos from the University of Cyprus in 2009 [2] which points out that children with dyslexia have a character age around $7-9$ years old.

Most children come from regular schools and they tend to have a lower achievement than the other students. According to the parents, their children are often considered as "stupid" students and have a below-average IQ. Elphie (in Imandala, 2009) agrees to this condition who says that children with dyslexia are often considered as children with low achievement. Meanwhile, based on the sex, relatively there is no a significant difference as seen in Table 2. Dyslexia disorder can occur to both male and female, but the number of male sufferers is more, which is seventeen people. Br. Michael Rutter has done a research to a number of children. Ten thousand children are given a reading test. The result is $17.6 \%-21.6 \%$ of boys and $7.9 \%-13 \%$ of girls who suffer from dyslexia (Liqouri, 2003)[3]. It means boys are more susceptible suffering from dyslexia.

Table 2.

\begin{tabular}{|l|l|l|}
\hline \multicolumn{2}{|c|}{ Sex of Respondents } \\
\hline Sex & Total & $\%$ \\
\hline Male & 17 & $57 \%$ \\
\hline Female & 13 & $43 \%$ \\
\hline Total & 30 & $100 \%$ \\
\hline \multicolumn{3}{|c|}{ Source: Research, 2017} \\
\hline
\end{tabular}

The following table shows the number of children with dyslexia based on their parents' background.

Table 3.

\begin{tabular}{|l|c|c|}
\hline \multicolumn{3}{|c|}{ Parents' Job of Respondents } \\
\hline Parents' Job & $\begin{array}{c}\text { Tot } \\
\text { al }\end{array}$ & $\%$ \\
\hline Labor & 5 & $17 \%$ \\
\hline Handyman & 5 & $17 \%$ \\
\hline Trader & 6 & $20 \%$ \\
\hline Entrepreneur & 9 & $30 \%$ \\
\hline Civil servant & 5 & $17 \%$ \\
\hline Total Source: Research, 2017 & $100 \%$ \\
\hline
\end{tabular}

Table 3 shows a various background of parents of children with dyslexia. It implies awareness and preparedness from the parents that need to be concerned about. They need to be ready, patient, and sincere to the condition they face. Then, they have to attempt to solve the issue of their children. The question is, is there any relationship between children with dyslexia and the parents' background? The data from Table 4 shows the parents' educational background whose children with dyslexia. It varies from primary school graduates until master degree

graduates. Although in Table 4, it is shown that parents with junior high school and senior high school background have the most children with dyslexia. However, it describes the educational situation in general from demography in Indonesia at the moment. Most Indonesian citizen graduate from junior high school and senior high school. Someone's educational background is suspected as his/her insights or knowledge towards a particular issue or problem, including dyslexia. 
Table 4.

Parents' Last Education of Respondents

\begin{tabular}{|l|l|l|}
\hline Parents' Education & Total & \% \\
\hline Master degree & 3 & $10 \%$ \\
\hline Bachelor degree & 5 & $17 \%$ \\
\hline Senior high school & 10 & $33 \%$ \\
\hline Junior high school & 9 & $30 \%$ \\
\hline Primary school & 3 & $10 \%$ \\
\hline Total & 30 & $100 \%$ \\
\hline
\end{tabular}

Source: Research, 2017

Based on the data, the majority of the respondent who suffers from dyslexia has parents with senior high school as their last education level. The number of it is ten people. The result is in a line with a research conducted by Timothy C. Papadopoulos from the University of Cyprus in 2009[4]. The result shows the data where most parents with dyslexic children have senior high school as their last education with $41.2 \%$. Meanwhile, in religion category, Table 5 is showing that how Islam gets the highest number of children with dyslexia. It is due to the demography of Indonesia as general. It implies dyslexia disorder on children does not depend on someone's religion.

Table 5.

\begin{tabular}{|l|c|c|}
\hline \multicolumn{2}{|c|}{ Religion } \\
\hline Islam & Total & $\%$ \\
\hline Christian & 3 & 0.9 \\
\hline Total & 30 & 0.1 \\
\hline \multicolumn{2}{|c|}{ Source: Research, 2017 } \\
\hline
\end{tabular}

The data from the previous tables show the information about dyslexia in some schools in Bandung. A social work as a professional help focusing on human and its environment will see the social life situation of the dyslexic children. Dyslexia as a learning disorder on children also forms a particular social situation on its environment, such as parents, school, friends, and so on. If nobody looks after this kind of situation wisely, it might bring about the children condition becoming contraproductive.

Ningsih and Kusumarini [5] state that dyslexia is one of the stuff in the field of language that handles learning issue for children with learning difficulty specifically. Dyslexia comes from the word $d y s$ which means

'difficulty' and lexia which means 'language'. Literally, dyslexia means a difficulty in reading letters in the written text. Furthermore, another term to use to explain children's difficulty in this area is word blindness or alexia proposed by William Pringle Morgan in 1986.

The word dyslexia was first conceived by Professor Rudolf Berlin in Stuttgart in 1887 in his monography entitled "Eine besondere Art der Wortblindheit (Dyslexie)". Prof. Berlin state that children with dyslexia symptom have obstacles in reading, writing, and spelling (Hammond and Hughes, 1993:3). Sanders and Meyers (1996) explain some typical obstacles in learning for dyslexic children, namely: (1) an obstacle in learning a language, (2) imbalance in intellectual ability, (3) inarticulate reading printed letters or words, (4) unable to write smoothly and properly, for instance, difficult to copy words from a board to a book, and (5) an obstacle in hearing and visual observation. Dyslexia is also a disorder with neurobiological disorder foundation marked by a difficulty in recognizing words properly and accurately, both in spelling and coding symbols (Ningsih and Kusumarini, 2011)[5]. Ningsih and Kusumarini (2011) conclude that the obstacles found in children with dyslexia are: (1) an obstacle in producing writing (fingers and hands movement), (2) an obstacle to shift the writing of letters, (3) not paying attention to the writing starting point, (4) an abnormal and huge handwriting and not using the principle of handwriting motoric (graphomotor principle), and (5) not understanding the rule of writing arrangement started with a letter, a word, and then a sentence.

A social work profession as a professional help with a tendency to disability group, including children with dyslexia, needs to develop a suitable knowledge, method, and skill for the disability group (Wibhawa et al., 2010; Raharjo, 2015; Raharjo, 2016). The establishment and utilization of treatment for children with dyslexia with communitybased need to be developed and maintained its existence as a source of treatment [6]. Dyslexic children are from a susceptible population

(community), which is a particular group in a community that often receives unfair, persecuted, and marginalized treatment as a consequence of a discriminative condition, economic crisis, or certain pressures[7]. There has to be collaboration from authorized sides, either government, privates, community, or social media (known as pentahelix). Conclusion The data from the field shows that most of the children with dyslexia in Bandung are boys from seven years old. The job and educational background of their parents are quite various. The family and close relatives of dyslexic children need to gain an intact knowledge and understanding regarding the symptoms and features of dyslexia. The nearest social environment of dyslexic children is an important part of a proper treatment for them. The other sources in treating dyslexic children formal and informal, institution-based and communitybased need to be done. There must be collaboration from various stakeholders in helping dyslexic children. Social work profession needs to understand intact the problems/obstacles faced by children with dyslexia, their family, environment, and the communities who care about dyslexia. In the future, there should be researches regarding disability, especially dyslexia in order to produce data and information as well as a development of proper methods and techniques for treating children with dyslexia.

\section{REFERENCES}

[1] G. A M and M. D, "Dyslexia: Advances in Cross-Level Research.," Charles A. Dana Research Institute, Boston, Research.

[2] P. T.C, G. G. K, and D. S, "Modeling of dyslexia: Is a unitary model of dyslexia possible? In H. D. Friedman and P. K. Revera (Eds.), Abnormal Psychology: New Research (pp. 47-81). Hauppauge, NY: Nova Science Publishers.," 2009. 
[3] B. G Cirstea, H. Kirchner C, and L. L, Pure Patterns Type Systems. In POPL, 2003.

[4] D. Friedman and P. K. Revera, "Papadopoulos, T. C., Georgiou, G. K., \& Douklias, S. . Modeling of dyslexia: Is a unitary model of dyslexia possible? In H. D. Friedman and P. K. Revera (Eds.), Abnormal Psychology: New Research (pp. 47-81). Hauppauge, NY: Nova Science Publishers.," Nova Sci. Publ., 2009.

[5] N. TWR and K. CD, "Hubungan Antara Memori dan Penderita Disleksia dalam Tinjauan Psikolinguistik.," Proceeding PESAT Psikol. Ekon. Sastra Arsit. Sipil, oktober 2011.

[6] R. ST, Pekerjaan Sosial Generalis: Pengantar Bekerja Bersama Organisasi dan Komunitas. Bandung: Unpad Press, 2015.

[7] R. ST, Keterampilan Pekerjaan Sosial: dasar-dasar. : . Bandung: Unpad Press, 2016. 